\title{
Crime and Punishments among the Goemai: A Preliminary Survey of Traditional Judicial Practices in North Central Nigeria
}

\author{
Jonah, Changwak Emmanuel \\ Department of History and International Studies, Nigeria Police Academy, Wudil. Kano State \\ Nigeria
}

\begin{abstract}
The paper examines the pre-colonial judicial practices among the Goemai of North Central Nigeria. It discusses their traditional methods of adjudicating crimes and punishment within the context of what constitute crimes against the laws of the land. From the analysis, the paper suggests that their pre-colonial system of ascertaining rights and wrongs were predicated upon the principle of fair hearing and administration of justice. It was upon this system of administration of justice that the present day customary laws were based. The paper derives inspiration from a variety of sources synthesized from published books, dissertations and theses, supplemented by oral accounts.
\end{abstract}

Keywords: Crime, punishment, Goemai, Judicial, North Central Nigeria

\section{Introduction}

Nigerian societies, before colonialism had practices that were unique to them. Among the Goemai of North Central Nigeria, there Pre-colonial justice system was a reflection of their general world outlook. The framework of their traditional system of justice was quite different from alien legal system imposed on the society (and other Nigerian societies) by colonialism. Although criticism abounds in colonial historiography that African past judicial practices are obsolete, unwritten and barbaric, interestingly, even the English Common laws which was introduced and today formed the basis of Nigerian legal system at sometimes in the past were unwritten.

\section{Goemai Land Within The Context Of The Central Nigeria}

The area called central Nigeria as the name implies can be found at the geographical centre of Nigeria. It is located between Latitudes $7^{0} 30$ North and $11^{0} 15$ North and Longitudes $4^{0}$ and $12^{0}$ East of meridian. It covers an area of approximately $342,390 \mathrm{Km} 2$ or 37 percent of the total land area of Nigeria. ${ }^{1}$ It is bordered to the East and West by Cameroon and Benin Republics respectively and the North and South by the Northern and Southern States. The area is sometimes referred to as the Middle Belt of Nigeria. It is structured into eight states of Benue, Kaduna, Kogi, Kwara, Niger, Plateau, Nasarawa, Taraba and FCT with an estimated population of over $18,009,696{ }^{2}$ This area is a home to many ethnic groups including the Goemai.

The word Goemai literary means "human" or "man". The actual meaning of the word is obscure, but it is used to describe the people who speak the Goemai Language with the same customs and traditions and recognized themselves as one. ${ }^{3}$ The Hausa and most colonial documents referred to the Goemai as Ankwai. ${ }^{4}$ The Goemai today are found in Shendam Local Government of Plateau State.

\section{Goemai Conception Of Crime And Justice}

The Goemai had their own style of referring to crime and justice in the period under review. Their conception, (which was not different from other societies in Nigeria), was a reflection of their belief system and cultural values, which evolved over time.The Goemai conceived crime as $B i$-Geoniang. ${ }^{5} B i$ - Geoniang, according to the Goemai was a term used to describe any deviant activities or actions that are not in concord with the laid down norms of the society. Such actions or activities are punishable based on the traditional mode of justice. Such activities includes theft, abduction, murder, adultery, fornication, encroachment others peoples farmland etc. the penalties for these crimes varied depending on the degree of harm it caused to either the person or the community at large.

In the case of justice, there were many styles among the Goemai on its conception and articulation. The Goemai describe justice as Bi- Geodiong or Shep. ${ }^{6}$ While the former means fairness, the later denotes judgment. Justice among the Goemai meant bringing the culprits to book and punishment rightly meted based on the intensity of the offence. 


\section{Structural Framework For Conflict Resolution}

The administration of justice was centered on the Council of elders known as Daskoom. The daskoom, together with the Long and with the consent of the people formulated the laws. Such traditional laws forbade individuals and groups from stealing, adultery, murder, encroachments in to both farm lands and fishing ponds, disregard to traditions such as not giving way when masquerade appeared, marriage that were not in conformity with traditions. ${ }^{7}$

Family quarrels, issues of divorce among others, were handled and thrashed out at the family level with the family heads as adjudicators. In the case of inter- family disputes, heads of different families involved would normally sit and deliberate on the matter. When the cases are unresolved, they were forwarded to the council of elders (Daskoom) for further consideration. Ndakek Daskoom was leader of the Council of elders. He was the oldest man in the council and led out in the discussion before any decision was taken. ${ }^{8}$

Cases were tried first by the family heads and when they failed, the cases were referred to the council of elders. Cases of murder were completely beyond the cane of the family heads. Murder cases were tried by the Daskoom. Punishments for murder cases were banishment or death penalty. Other crimes attracted payment of livestocks and local brewed beer, depending on the gravity and intensity of the crime. Most often than not, fines were imposed on offenders. The fines included items such as millet, goats, chicken, sorghum, local brewed beer. ${ }^{9}$ Besides deaths, the Daskoom were also responsible for trying other criminal cases such as abduction and conflict leading to death whereby the perpetrators of such crimes are either banishment or killed. ${ }^{10}$

\subsection{Securing the Attendance of Parties and Witnesses}

Complaints of cases especially murder, land disputes, encroachment in to fishing ponds and farmlands, abduction, theft and other related offences that contravened the norms of the society were reported to the Daskoom three days before the court converged. ${ }^{11}$

In the court, methods of conducting trails was informed and varied with the nature of the offences. If the case was that of dispute between two parties, the two contenders reported the case to the council of elders through their family heads who were also responsible in compelling their appearance before the council of elders or the Ndakek Daskoom. The complainant was asked to state his case and the defendant would respond. Both contenders were subjected to questions from members of the Daskoom or tribunal. The Ndakek was president of Daskoom. In the case of murder, abduction and theft which the society frowned at most, most of the questioning came from the Ndakek Daskoom. After cross-section examination the council then entertained witnesses from both sides. The witnesses were asked to give their own version of the disputes after which the case was thrown open for discussion among the council. It was after the discussion that punishments were pronounced based on the intensity of the offences so committed. ${ }^{12}$

\subsection{Court Location and Sitting Arrangement}

The traditional court among the Goemai was situated in an isolated and specially carved area called Ludas. ${ }^{13}$ Although each family had it own Ludas where minor cases were tried, cases that seemed to affect the generality of the society were tried at the greater Ludas. The greater Ludas was situated at the outskirt of the town. It was more or less a religious shrine set aside for the administration of justice and other related religious practices.

The sitting arrangement in the Ludas was such that the presiding judges who were the Council of elders sat on well arranged logs of woods carved in such a way that each Daskoom was entitled to one. The logs were arranged in almost square form with one distinct seat reserved as the seat of the Ndakek Daskoom. The accused and the accuser sat within the square on the ground while the witnesses and other listeners stood outside the square. ${ }^{14}$ This sitting arrangement was only distorted when the case was appealed to Dabit. In this case, the Dabit presiding over the case sat in front on a mortar while others still maintained their sitting arrangement. ${ }^{15}$ This sitting arrangement when trying cases can be illustrated in the diagram below: 
DABIT/NDEKEK DASKOOM
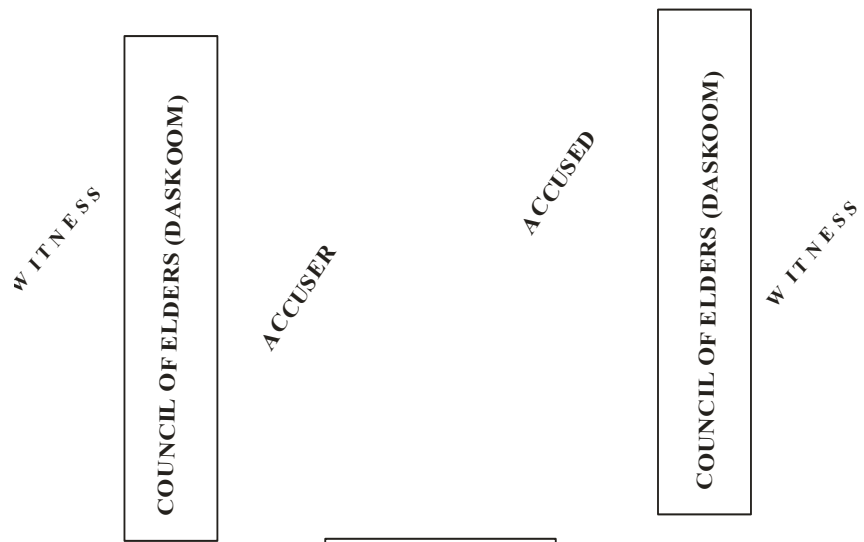

LISTENERS

Figure 1: Court Sitting among the Goemai. Source: As witnessed by the Researcher during field work.

\subsection{Verdict/ Punishment}

In the pre-colonial Goemai society, punishment meted out or verdict passed varied, depending on the gravity of the act in question. These ranged from warnings, imposition of fines (often in form of domestic animals such as fowl and goats) to, in rare cases, capital punishment. For instance, in cases of insubordination, slender or wife battery, the culprit was either cautioned and educated to appreciate the significance of discipline and respect for elders or those in authority or fined in accordance to the gravity of the offence. ${ }^{16}$ In the case of theft, adultery, fighting, culprits were required to provide some numbers of livestock (this will be show in table 1 below) based on the gravity of the offence.

Livestcks procured from such fine were taken to the shrine (Ludas) by the Council of Elders (daskoom) for sacrifice in order to appease the gods and venerate the ancestors, in the belief that peace may reign in the community. $^{17}$

In rare instances where death penalty was considered appropriate, the offenders were not executed in public. Indeed, public execution among the Goemai was thought to be inconsistent with the sanctity of human life. Thus, the offender was taken to the forest and eliminated after which the story told to women and children was that the person was seized and killed by a wild animal. Beside death penalty, banishment was another option for gravious crimes such as murder, manslaughter and abduction. ${ }^{18}$ The verdict for various crimes is illustrated in the Table below:

Table 1: Crimes and Accompanying penalties in the Goemai Traditional Judiciary System

\begin{tabular}{|l|l|}
\hline CRIMES & PENALTIES \\
\hline Murder & Banishment or Death \\
\hline Abduction & Banishment \\
\hline Theft & $\begin{array}{l}\text { Items stolen returned, Plus } 3 \text { goats, } 3 \text { chickens and some quantity of } \\
\text { local brew. }\end{array}$ \\
\hline Adultery & 2 goats, 2 chickens Plus local brew (Burukutu) \\
\hline Fighting & 1 Chicken each plus local brew \\
\hline Encroachment of farmland & Surrender the land plus payment of 3 chickens plus local brew \\
\hline Encroachment of fishing ponds & Surrender the catch plus 1 goat, 2 chickens plus local brew. \\
\hline
\end{tabular}

SOURCE: Author's field work 2009

\subsection{Appeal}

Given that the structural framework for dispute settlement involved the family, the council of elders (daskoom) and the Dabit, there was room for appeal. Whenever a party was aggrieved and not satisfied with judgments and punishment it will appeal to the Daskoom for hearing. If the aggrieved was still not satisfied with the verdict at the family level could appeal to the Daskoom or Council of elders. The daskoom did not interfered with decision of the except where there were evidence of abuse of office or perversion of justice. One can also appeal judgments dispensed at the Daskoom level to the Long court. Whenever it superseded the Long Courts, it was forwarded to the Dabit for final adjudication. ${ }^{19}$ The Dabit among the Goemai was a powerful masquerade 
which in terms of administering justice, was regarded as the highest court of appeal. The Dabit had the power to question the activities of both the both the Daskoom and the Long and even punish them. Aggrieveness beyond this court was left to providence. ${ }^{20}$

\section{Changes in Judicial Practices as a Result of External Contacts}

Contact with the outside world brought considerable shifts and changes in the judicial practices of the Goemai during the period under review. Contact with the outside world was mainly through trading activities. The Goemai was in contact through long distance traders from places sucsh as Borno and Kano. In the jihad period, there were Hausa, Fulani and Kanuri in area especially around Kwande and kurgwi areas. Their presence brought about changes and shifts in the traditional system of justice.

From the extant sources, it is clear that the Goemai had contacts through long distance traders with the outside world with whom they intermarried. ${ }^{21}$ These intermarriages brought about cultural fusion which in the course of many generations led to changes in their cultural and political structures. It also led to the adoption of honorary Hausa political titles such as Madaki, Galadima etc. This invariably affected their judicial practices (since both were intertwined) by changing most of the punishment. For example the penalties for murder were no longer death but banishment to either Kano or Borno or Yelwa. ${ }^{22}$

Another notable shift and change occasioned by this contact was the introduction of new practices that was not hitherto known among the Goemai. The case in point was the bori cult (spirit possession) which was common practice among the Goemai . Bori cult was adopted from the Hausa and has become an accepted practice up to date. The implication of this was that both the political and judicial institution of the Goemai society have changed to accommodate the new practice ${ }^{23}$. Their political and judicial process witnessed a deliberate shift to accommodate the bori cult despite its diabolic practices.

The establishment of aman or amana contacts between the vassal states and the Plateau societies promoted peaceful coexistence in the pre-colonial period. This provided diplomatic immunity for persons and properties of Muslims and non-Muslims found in each other boundaries. It also stimulated the growth of economic exchange and cultural interactions between the different societies and the emirate powers. ${ }^{24}$ In this process, few cultural practices were exchanged like the use of Hausa dresses, bilateral ties, etc. This brought about changes in the political structures. The functions of the priest chiefs among the Goemai was affected as they became more involved with the outside world.

\section{Conclusion}

The paper has examined the pre-colonial process of administration of justice among the Goemai of North Central Nigeria. The Goemai evolve a forward looking system administration of justice which in the course of many generations has formed the basis of the present day customary laws in the North Central Nigeria. The study also examined shift and changes in the pre-colonial judicial practice occasioned by trade with other communities, the presence of Hausa as a result of the Jihad. Despite the impact of external factors many aspects of the traditional system have survived up the present.

\section{Endnotes}

[1]. Patrick D.D, "Aspect of the Geography of Central Nigeria Area” In A.A Idrees, Y.A Ochefu (edited), Studies in the History of Central Nigeria Vol 1 (Lagos:CSS Limited;2002) p.3

[2]. Patrick D.D, "Aspect of the Geography of Central Nigeria Area" In A.A Idrees, Y.A Ochefu (edited), Studies in the History of Central Nigeria Vol 1 (Lagos:CSS Limited;2002) p.3

[3]. B.F Bawa, "Traditional Authority among the Goemail Speaking group of the Plateau State: A study of the Changing role and Power from pre-colonial period to Present" M.A Dissertation, University of Maiduguri. 1984. P.1

[4]. B.F Bawa, "Traditional Authority among the Goemail Speaking group of the Plateau State: A study of the Changing role and Power from pre-colonial period to Present" M.A Dissertation, University of Maiduguri. 1984. P.1

[5]. Bi-Geoniang is the Goemai version of crime. It encompasses all activities and action that the societies frowned at and are punishable by the law of the land.

[6]. Oral interview with Longzem Shikbit, 50 years, $18^{\text {th }}$ April, 2009.

[7]. Oral interview with Sabo Lumi, 69 years, $21^{\text {st }}$ April, 2009.

[8]. Oral interview with Sabo Lumi, 69 years, $21^{\text {st }}$ April, 2009.

[9]. Oral interview with Longmaar Shindwar 70 years, $14^{\text {th }}$ April, 2009.

[10]. Oral interview with J.S, Madugu 72years, $26^{\text {st }}$ August, 2009.

[11]. Oral interview with Leonald Shaiyen, 78 years, $31^{\text {st }}$ August,2009.

[12]. Oral interview with Leonald Shaiyen, 78 years, $31^{\text {st }}$ August,2009.

[13]. Oral interview with Danladi Hoomvel, 60 years, $26^{\text {th }}$ August,2009.

[14]. Oral interview with Longfer Aboki, 51 years, $29^{\text {th }}$ August,2009.

[15]. Oral interview with Longfer Aboki, 51 years, $29^{\text {th }}$ August,2009.

[16]. Oral interview with Leonald Shaiyen, 78 years, $31^{\text {st }}$ August,2009.

[17]. Oral interview with Leonald Shaiyen, 78 years, $31^{\text {st }}$ August,2009.

[18]. Oral interview with Leonald Shaiyen, 78 years, $31^{\text {st }}$ August,2009.

[19]. Dabit is a strong masquerade revered and feared among the Goemai group up till date. During the pre-colonial period, it served as the apex court of justice beyond which issues are left to providence. 
[20]. Oral interview with Leonald Shaiyen, 78 years, $31^{\text {st }}$ August, 2009

[21]. Jonah, C.Emmanuel, "Development of the Judiciary in the Plateau Province: A Study of the Lowland Division, 1926-1960" Unpublished M.A Dissertation, School of Postgraduate Studies, Nasarawa State University, Keffi.2010. P.

[22]. Jonah, C.Emmanuel, "Development of the Judiciary in the Plateau Province: A Study of the Lowland Division, 1926-1960" Unpublished M.A Dissertation, School of Postgraduate Studies, Nasarawa State University, Keffi.2010. P.

[23]. Jonah, C.Emmanuel, "Development of the Judiciary in the Plateau Province: A Study of the Lowland Division, 1926-1960" Unpublished M.A Dissertation, School of Postgraduate Studies, Nasarawa State University, Keffi.2010. P.

[24]. Nengel, J.G "Some consideration of the Relation Between the Sokoto Caliphate and the Polities of Central Nigerian Highland" In A.A Idrees, Y.A Ochefu (edited), Studies in the History of Central Nigeria Vol 1 (Lagos:CSS Limited;2002) P.577-593 